\title{
O NASCIMENTO DA ESTRATÉGIA: NOTAS PARA UMA INTERPRETAÇÃO DA EMERGÊNCIA DA FILOSOFIA
}

\author{
[The birth of the strategy: notes for an interpretation of the emergency of \\ philosophy]
}

Felipe Luiz*

\begin{abstract}
Resumo: Variadas visões concorrem no que tange à elucidação tanto do caráter quanto das origens da filosofia. Questões gêmeas, as quais geralmente vêm de mãos dadas, mesmo porque parece que a elucidação de uma conduz à da outra. Nosso intento é o de polemizar com algumas das interpretações destas questões — particularmente Heidegger, que entende a filosofia como historial; e Hegel, cuja compreensão é teleológica — defendendo uma visão estratégica da filosofia, à moda de Foucault, cujos objetivos cumpre aclarar naquilo que chamamos de filosofia da guerra, gênero específico de metafilosofia.
\end{abstract}

Palavras-chave: Filosofia da guerra, estratégia, conceito de filosofia

The birth of strategy: notes to a philosophy's emergency interpretation

Abstract: There are many ways to understand the origins and character of philosophy. These are twin questions, coming always together, also because the elucidation of one conducts to the elucidation of the another. We intend to polemize with some interpretations, as that one of Heidegger (who understands the philosophy as historial) and the another, of Hegel (who understands philosophy as teleological). For us, philosophy must be understood as a strategy, in the mode that Foucault had predicted, in the direction of the constitution of a war's philosophy, metaphilosophy genre.

Keywords: Philosophy of war, strategy, concept of philosophy

\section{Introdução ${ }^{1}$}

A noção foucaultiana de discurso (CASTRO, 2009, pp. 117-123) talvez exemplifique para certo senso comum filosófico, as dificuldades pelas quais passaram inúmeros textos hoje seminais desta disciplina. Como se sabe, por este conceito indicase a produção, circulação, ampliação e restrição do saber considerado em sua materialidade. No caso que ora tratamos, enfocamos o problema dos primeiros filósofos e os percalços que seus escritos passaram ao longo de sua história.

\footnotetext{
* FFC-UNESP/Marília. Foi Bolsista PIBIC-CNPQ, atuando no tema Michel Foucault e epistemologia política da psiquiatria. Posteriormente pesquisou as relações de Foucault com o pensamento político anarquista. Atualmente dedica-se ao desenvolvimento da noção de Filosofia da Guerra, com financiamento BAAE-UNESP.

${ }^{1} \mathrm{O}$ texto que segue sintetiza uma pesquisa que vimos desenvolvendo há alguns anos, cujo escopo é uma tentativa de, a partir de desenvolvimentos pós-estruturalistas, buscar entender a emergência da filosofia, empreendendo uma reflexão sobre seu caráter. Os tópicos que seguem são, portanto, resumidos, e devem ser plenamente desenvolvidos em nossa monografia de conclusão de curso.
} 
Assim, se mesmo um Santo Tomás de Aquino não teve acesso senão incompleto, e de segunda mão, da produção aristotélica (LIBERA, 1990), o que dizer dos chamados pré-socráticos, dos quais, muitas vezes, não restou senão fragmentos ou, em alguns casos, pequenos comentários, sejam antigos, sejam modernos, a chamada doxografia, ao mesmo tempo em que nos chegam notícias de produções muito maiores? Em fato, é a partir do século XVI que os textos antigos começam a receber um tratamento que terminará por lhes dar a forma canônica; mas, sobretudo, somente com a grande onda filológica que toma os meios cultos europeus, entre fins do século XVIII e XIX que os escritos dos pré-socráticos começarão a ter tratamento filosófico adequado, sobretudo pelas mãos de variados intelectuais alemães (BERGE, 1969).

Talvez estes percalços justifiquem as dificuldades inerentes ao tratamento que receberam e é neste ponto que gostaríamos de insistir. Muitas vezes tratados como filósofos menores - talvez com as exceções de Parmênides, tido como criador do princípio da identidade depois formulado por Aristóteles, e nodal na lógica; e de Heráclito, que trabalhou sobre o termo filósofo (HEIDEGGER, 1957, p. 24), o qual influenciou Hegel —, em fato a riqueza das proposições e o fato de ali se ter principiado, segundo toda a tradição, a própria especulação filosófica, dá ensejo para que seja nos pré-socráticos que se deva buscar o basilar da emergência desta disciplina, a filosofia.

No caso especifico de nossas investigações concernente ao caráter da filosofia, sobre o qual vimos insistindo em interpretar-lhe como fundamentalmente belicoso e político (LUIZ, 2010b; idem, 2013a; idem; 2013b; idem, 2014a; 2014b), o ensejo o mais profícuo para demonstrar a justeza de nossas colocações vem a lume exatamente nos pré-socráticos. Contrariamente ao que se possa pensar, não se trata de simplesmente seguir a senda heideggeriana, que aponta genealogicamente o termo philosophia e sua etimologia como a via correta para estabelecer o caráter da mesma (HEIDEGGER, 1957). Ao contrário, é pelo gênero de reflexão e, também, pela situação cultural — pelas mudanças ocorridas nos conceitos filosóficos fundamentais dos mesmos conformes às traduções e interpretações - que cremos que é nestes filósofos que se pode mostrar este caráter estratégico-político da filosofia.

\section{A noção de estratégia e o pensamento de Michel Foucault}


Quais motivos nos levam a assim pensar o saber filosófico enquanto estratégico? Conforme já exposto (LUIZ, 2014b), primeiro é necessário repisar a conhecida distinção elaborada pela doutrina militar entre tática e estratégia, sendo esta um objetivo de longo prazo (permanentes ou de maior monta), conquanto a segunda seriam os movimentos que conduzirão à consecução dela ${ }^{2}$. Como nos inserimos na esteira das pesquisas foucaultianas relativas à constituição das relações de poder no Ocidente, é mister precisar diferenças especialmente no que tange à noção de estratégia. $\mathrm{O}$ senso comum, filosófico ou não, remeteria o termo estratégia ao sujeito que a pensou, quer dizer, ao estrategista; em outra oportunidade (LUIZ, 2014a) ironizamos esta noção com o termo gênio estrategista, quer dizer, como se as estratégias fossem dependentes da consciência; para Foucault, entretanto, a questão se assoma de outro modo, o que nos implica certa digressão.

No curso Em defesa da sociedade Michel Foucault busca problematizar algumas posições e temáticas da filosofia política, notadamente alguns modelos analíticos das relações de poder. Para ele, estas análises até então teriam sido marcadas por uma dupla forma de economismo, de um lado aquela liberal - que pensava as relações de poder sob a forma-mercadoria, ou contrato, entendendo o poder como algo que se dá, troca ou suprime - de outro, o marxismo - para o qual as relações de poder devem ser entendidas em remissão às relações de produção e às classes nelas imiscuídas. A seu turno, Foucault intenta elaborar uma analítica do poder a partir daquilo que chama de modelo de Nietzsche ou, mais comumente, modelo da guerra (LUIZ, 2010a); neste, as relações de poder são entendidas primeiramente, como relações, não como coisas; segundo, elas se fundam em si mesmo, sem remissão a outras instâncias; também elas, as relações de poder, seriam sempre instáveis, quer dizer, dinâmicas, de modo que elas implicam em um investimento constante, o que também faz com que seu duplo, a resistência ou o contra-poder, seja sempre possível. Dentre outros pontos, salientamos também a reticularidade das relações de poder, ou, para repisar o repisado, o fato de ele constituir-se em microrrelações as quais apoiam e possibilitam os grandes esquemas de poder - as dominações cotidianas mais comezinhas, corporais mesmo, seriam, pois, o sustentáculo, por exemplo, das grandes formas estatais de governo (LUIZ, 2010a).

\footnotetext{
${ }^{2}$ A definição de estratégia e tática é complexa, múltipla, envolvendo ampla gama de variáveis e de conceituações distintas. Em nosso caso específico, buscamos sintetizar, para fins didáticos, esta noção, sobre a qual tornaremos, com a profundidade adequada, em novo estudo, brevemente. Uma boa introdução ao tema se encontra em Escola de Comando e Estado-Maior do Exército; Introdução à estratégia, RJ: ECEME2010.
} 
A partir deste modelo de guerra, Foucault lança mão de todo um vocabulário bélico para suas análises: estratégias, táticas, alianças, dispositivos, aparatos, técnicas. No entanto, a noção de estratégia de Foucault tem lá suas particularidades; tendo em vista que ele parte de uma ontologia política do saber (LUIZ,2010b), esta redunda no fato de que conhecer, isto é, dar sentido a certo objeto, é constituí-lo enquanto tal, o que, por seu turno, deixa de fazer remissão a um sujeito constituinte, seja cartesiano seja fenomenológico, deitando o peso analítico nas estruturas ou relações que fundam ao engendrar estes mesmos sujeitos, de tal feita que o próprio acontecimento(CASTRO, 2009, pp.24-28), com seu espaço, tempo e relações, insere-se em uma estratégia na precisa medida em que acontece. Assim é que se torna possível falar em uma estratégia carcerária ou em outra psiquiátrica sem que elas tenham sido formuladas por um gênio estrategista: o fato de ocorrerem as inscreve-se em um dispositivo que aos poucos digamos taticamente - assim se estruturou. (LUIZ, 2010b). Trata-se, pois, de uma estratégia sem estrategista ou de uma estratégia sem sujeito, termos que aparecem em textos de Foucault (2007, pp. 251-258).

\section{Algumas visões relativas ao nascimento da estratégia}

Dentro desta grade teórica é que buscamos dar resposta à questão: o que é isto, a filosofia? De saída, precisemos, é necessário acontecimentalizá-la, dar seu lugar, sua história, ou seja, inscrevê-la nas relações que a constituíram, algo que já tivemos ensejo de realizar, ao menos em embrião (LUIZ, 2013a), embora cumpra retornar e aprofundar nossas análises. Assim, sendo cada filosofia em particular uma tática dentro de uma estratégia mais ampla, na medida em que aconteceram, seria necessário entender para onde aponta a filosofia, ou, precisando, qual seria o objetivo estratégico da assim já dita rainha das ciências. Martin Heidegger utiliza o conceito de historial para determinar isto (HEIDEGGER, 1957; e idem, 1987): a filosofia carrega um destino, o destino da humanitas do homem, ela deu-lhe a direção, na clareira do ser, especialmente pelo fato da técnica e do correlato esquecimento do ser lhe serem tributárias; a técnica, em fato, quer dizer, exatamente, que as primeiras reflexões filosóficas, àquelas dos présocráticos, que abordavam a arché da physis e a physis da physis — termos sobre os quais retornaremos - foram progressivamente abandonados em benefício de análises que privilegiam o ente, quer dizer, pelo ganho de corpo e de peso progressivo da técnica — a investigação sobre a entidade de entes específicos —, que terminaria por ter em 
mãos o próprio destino do globo ao passo que redundou no fabrico da arma atômica. Discordamos desta análise de Heidegger, e teremos, também, chance de explicar os motivos.

Outras análises nos interessam neste ponto, além daquela do mestre da Floresta Negra, são, nomeadamente, as de Nietzsche, relativas ao apolíneo e ao dionisíaco; a de Hegel, que entenderá os primeiros filósofos enquanto etapas do processo de autoconhecimento do espírito; e a de Foucault que, ao comentar Deleuze, apontará que a questão central seria a de compreender o platonismo como uma não-filosofia que, assim, teria buscado, ao longo do tempo, suprimir as análises propriamente filosóficas, além de estar na raiz do principal princípio de restrição da fabricação e circulação de discursos, a vontade de verdade.

Primeiramente Nietzsche (NIETZSCHE, 1999). Uma de suas interpretações do período pré-socrático vem à lume ao considerar as vicissitudes da arte grega, para tanto tomando que dois impulsos competiam no período, sendo um o apolíneo e o outro o dionisíaco, em referências rasgadas à mitologia helênica. Tratando da origem da tragédia, Nietzsche afirma que estes dois impulsos concorreram para tanto e que Sócrates foi nodal para o predomínio de um sobre o outro, tal seja o apolíneo, e o fim da tragédia grega clássica. $\mathrm{O}$ apolíneo é identificado com o onírico, com a forma, a clareza, enfim, com o princípio de individuação - lembremos que aqui se trata de um Nietzsche sobremaneira schopenhauriano, e que, na filosofia deste, de passagem, o ser ele mesmo seria uma Vontade, a qual se individua na idéia platônica e que, por sua vez, se individua nas coisas existentes, as quais assim seriam cognoscíveis em decorrência do princípio da razão, o qual está em cada sujeito em particular; este mesmo princípio que torna possível o conhecimento teórico seria impeditivo do conhecimento do ser-em-si, o qual somente pode dar-se por meio da arte que, assim, massacra a existência do sujeito, no sentido do sublime kantiano, o qual passa a compreender-se como parte desta Vontade (SCHOPENHAUER, 2003); já o dionisíaco, seria a embriaguez, o extático, a volúpia não licenciosa. Sócrates, o primeiro "homem teórico", tinha uma (...) “inabalável fé de que pensar pelo fio condutor da causalidade, atinge os abismos mais profundos do ser e que o pensar está em condições não só de conhecê-lo, mas inclusive de corrigi-lo" (NIETZSCHE, 2003, p. 93). O predomínio da filosofia de Sócrates é análogo ao predomínio do teatro de Eurípedes - que muda o papel do coro e traz para a 
cena a vida do homem comum —, ambos implicando o fim do mundo helênico clássico, ambos já sinais do enfraquecimento de uma civilização, que terminará por nos conduzir ao domínio escravo, quer dizer, ao cristianismo, e a todos os problemas que Nietzsche enxerga neste. Para o autor do Zaratustra, portanto, a filosofia platônico-socrática demarcaria uma clivagem no mundo grego e, depois, em outros textos (NIETZSCHE, 1978), faz apreciações positivas dos pré-socráticos, ainda que críticas.

Também para Foucault Sócrates, ou melhor dizendo, Platão seria peça chave para a compreensão do que se passou na filosofia antiga: "E se definíssemos em última instância filosofia como qualquer empresa encaminhada a inverter o platonismo? Então a filosofia começaria desde Aristóteles e não com Platão" (FOUCAULT, s/d, p. 46). Em fato, na interpretação foucaultiana o marco decisivo que representaria a filosofia de Platão seria a de ter posto à baila uma crescente vontade de verdade que serviu, historicamente como princípio de restrição de discursos, quer dizer, como uma força que divide os discursos entre dois tipos, o verdadeiro e o falso, tema sobre o qual já nos debruçamos (LUIZ, 2008, pp. 194-207). Se parece, ao menos na bibliografia consultada, que Foucault não chega a debruçar-se sobre os pré-socráticos parecendo, mesmo, excluí-los do empreendimento filosófico, para nós é interessante notar o papel central, divisor de águas que o mesmo atribui a Platão.

Quanto à Hegel nos limitaremos a pontuar suas interpretações dos distintos pensadores pré-socráticos como, no máximo, elaboradores de conceitos que, por uma espécie de soma filosófica, acumulam-se rumo ao conhecimento do espírito, rumo à sua maturidade. Podemos chamar o gênero de pensamento hegeliano de teleológico e imediatamente oposto àquele sobre o qual ora trabalhamos - estratégico - e teremos ensejo de, no momento correto criticá-lo adequadamente. Alguns exemplos da posição de Hegel manifestam-se, por exemplo, em sua apreciação de Heráclito: para ele, os eleatas ainda estavam no entendimento abstrato, posto que afirmavam que o ser é, ou seja, que o verdadeiro é o ser, e Heráclito teria posto pela primeira vez a noção da igualdade entre o ser e o não-ser, quer dizer, teria entendido que o absoluto é a unidade do ser e do não ser, e seria aí o elemento onde o verdadeiro se daria; enquanto nas primeiras filosofias não haveria movimento, Heráclito, diz Hegel, colocaria o mesmo, suprassunção entre o ser e o não-ser, enquanto princípio, os quais ele mesmo, Hegel, teria seguido em sua Lógica: Heráclito aparece como o formulador da noção de devir, 
em contraposição ao imobilismo da escola eleática, seja seus representantes Zenão ou senão, por exemplo, Parmênides. Para Hegel, portanto, não se tratam de duas distintas interpretações sobre a physis da arché: uma suprassume a outra, na medida em que compreende melhor o caráter do absoluto ele mesmo; e, da mesma forma, Heráclito teve de ser suprassumido, na medida em que, por exemplo, não reconhecia a essência da idéia como universal ou, senão, por não ter formulado como o Logos chegava à consciência. Nas correntes de ferro do processo de autoconhecimento do ser, Heráclito e os eleatas seria elos opostamente concordantes: não perspectivas diferentes em luta, mas contrapontos harmônicos no seio do ser que se autoconhece. Este posicionamento de Hegel decorre de sua compreensão segundo a qual a filosofia tem um objeto, tal seja, o absoluto, que conhece através de um método análogo ao científico. Nestes marcos, posto que há uma finalidade na filosofia — conhecer o absoluto — , há também um progresso na consecução deste telos, em uma ordem necessária de filósofos e respectivas filosofias, cada qual mais concreta que a outra, quer dizer, mais determinada nesta finalidade ${ }^{3}$. É possível, portanto, falar em uma sucessão onde cada filósofo contribui com um quinhão de reflexão na concreção necessária do telos filosófico (HEGEL, 1983).

Já em Heidegger encontramos outras determinações quanto às origens e rumos da filosofia. Para ele é a remissão às suas origens que determinariam os conhecimentos das mesmas. Ele entende que as reflexões dos primeiros filósofos enfocavam, de forma geral, o ser do ente, quer dizer, não a entidade de um ou outro ente, mas do ser ele mesmo, ou seja, eram reflexões não propriamente ontológicas, mas que apontavam no sentido da constituição de uma ontologia, tendo em vista que o homem é ex-sistente, quer dizer, é pastor do ser, aberto para a verdade deste. Ao longo dos séculos, pelas distintas mudanças que a disciplina passou, houve um esquecimento desta senda e a reflexão propriamente filosófica foi abandonada por uma forma específica, técnica de pensar, a qual a Lógica demonstra:

a Lógica é a sanção desta interpretação [do pensar enquanto técnica] que começa com a Sofística e Platão (....) o pensar é rigoroso não pela exatidão artificial — técnico-teorética dos conceitos —, mas por dizer e permanecer

\footnotetext{
${ }^{3}$ Insistimos na polissemia do termo necessário, especialmente na inexorabilidade que denota, utilizado no texto hegeliano ao qual ora nos reportamos, mas também presente em outras reflexões do suábio, como na Fenomenologia do Espírito.
} 
no elemento do puro ser deixando-o imperar (HEIDEGGER, 1987, p.

Seria no âmbito específico da linguagem que o pastoreio do ser pelo homem ocorreria, ou, em outra forma, que a verdade do ser abrir-se-ia ao homem. Assim, de um lado, o domínio da opinião pública e, de outro, o da metafísica da subjetividade, do qual aquela seria expressão, seriam entraves para que o homem retomasse sua morada junto ao ser. Para tanto é necessário que a ex-sistência do homem seja pensada, pois é ela sua essência; a metafísica interrogaria o homem a partir de sua animalitas, impedindo, pois, que se o pense a partir do que caracteriza sua ex-sistência, o acesso à linguagem, pois é nesta que o homem expõe-se à verdade do ser, ligando, assim, seu destino ao dele. "O homem atem-se primeiro e para sempre apenas ao ente. Quando porém o pensar representa o ente enquanto ente, refere-se certamente ao ser (idem, p. 55), de modo que a questão do ser não é posta seguindo a questão do ente e a Metafísica é incapaz de pôr esta questão na medida em que somente conhece o ser enquanto idea, tal seja, enquanto representação categorial elaborada a partir da subjetividade; em suma, o domínio da metafísica, por exemplo, através da teoria da causas de Aristóteles ou através das distintas formas de metafísica da subjetividade, fez esquecer a verdade do ser. Ainda segundo Heidegger, o ser dá-se na linguagem pela palavra dos pensadores essenciais, o que explica também porque a filosofia é historial - é por meio dela que o destino do ser liga-se ao destino do homem, e o esquecimento da dimensão ex-sistencial do ser tem, pois, como se vê, implicações no próprio destino do que veio a se constituir como civilização global e atômica; em suma, "o ser enquanto destino que destina à verdade permanece oculto (...) é por isso que se torna necessário pensar este destino sob o ponto de vista ontológico-historial (idem, p. 66). Marque-se que também para Heidegger há um período pré-platônico no qual o vicejar da filosofia seria mais autêntico, mais ligado à constituição de um pensamento efetivamente ontológico, e que os caminhos e descaminhos pelos quais passou a filosofia determinaram o próprio destino do homem enquanto ente aberto à compreensão do ser, a qual somente se faria frente ao inefável do nada, da nadificação.

\section{Apontamentos para uma compreensão estratégica da filosofia}

Embora discordemos do que foi acima apontado, de Heidegger, de maneira geral, uma de suas afirmações nos é valiosa: "todo questionamento filosófico repercute 
na existência" (HEIDEGGER, 1987, p. 70). Contudo não a devemos entender nem em termos de luta entre apolíneo e dionisíaco, tampouco enquanto autoconhecimento teleológico do espírito, muito menos enquanto luta contra o platonismo. De Heidegger, a nosso ver, a noção de historial é a que melhor dá conta de caracterizar o empreendimento filosófico, mas à nossa via, que segue.

Para nós, interpretar a filosofia como estratégia pode se dar por duas sendas opostas: a primeira se dá a partir de certa interpretação de alguns termos chave do pensamento dos pré-socráticos, posição sobre a qual insistiremos no presente texto; a segunda passa pelo entendimento da filosofia enquanto uma estratégia sem sujeito, de modo que, seu surgimento e embates onde se inscreveu já a constituiriam, enquanto tal, em um grade estratégica. Em ambos os casos, a nosso ver, aplica-se a noção de estratégia sem sujeito, sobremaneira no primeiro.

Portanto, em primeiro lugar trata-se de uma questão de entendimento dos termos geralmente apontados como chave nestas filosofias préplatônicas como, por exemplo, o termo arché, introduzido por Anaximandro, como nos lega a tradição, o qual é traduzido, geralmente, como princípio, aparentado ao verbo archein; no entanto há também outro sentido do verbo archein, bem como outras palavras derivadas desta mesma raiz: trata-se de tomá-lo na acepção de "comandar" e, daí, a noção de arconte, magistrado, cujas tarefas, dentre outras, implicavam-se exatamente a guerra, e muitos outros termos correlatos. Arché tem muitos significados, um dos quais é império, mas também comando, como ademais, em seu sentido mais usual, princípio.

Do mesmo modo a noção de logos, com raízes comuns com o verbo légein, "dizer", "falar", dentre outra pletora de sentidos, mas também com logisdomai, “raciocinar", "calcular”. As traduções grassam seja como palavra, seja como discurso, seja, mesmo, como razão, mas com muitas outras definições; seu significado original indica "selecionar", “coligir" e "enunciar". Da noção de logos, introduzida pelo Efésio, virá, como se sabe, o sufixo -logia e a própria palavra lógica, ambas assimiladas ao empreendimento científico, o qual redunda naquele técnico. Em fato, contudo, o logos deve ser entendido em contraposição ao epos (BERGE, 1969, 90-132), aproximadamente o discurso da épica; o epos compartilha a raiz com eipein, que é 
exatamente, o aoristo ${ }^{4}$ de légein; a oposição logos-epos deve ser entendida em um marco estritamente de renovação, de contraposição ao mito - quer dizer, os mitos formadores da paidéia grega. Não queremos com isto afirmar um Heráclito ateu, mas sim um oposto aos mitos formadores da mocidade grega, como Hesíodo e Homero ${ }^{5}$. Heráclito compreendia o epos como a "linguagem inexpressiva do vulgo" (BERGE, p. 90) e na literatura que o antecede o epos significava a palavra humana ou divina, e rareia o termo logos, e, quando este aparece, seu sentido é o mesmo que o de epos, pelo menos até Teógnides. É Heráclito o introdutor desta distinção. O professor Berge conclui que o "epos era a língua da aristocracia argiva e aquéia, daquela sociedade fechada ao homem comum, e daquela outra, toda inacessível, da família olímpica" (BERGE, 1969, p. 111); e que Homero e Hesíodo dificultavam que se ensinasse à mocidade a moderação, quando seus deuses não são moderados: 'a épica solapava os fundamentos da polis: encaminhava à asebeia [impiedade], ao ateísmo, era antipatriótica" (BERGE, 1969, p. 117). Em suma, conquanto o logos revela o invisível da physis (que "ama esconder-se", DK 123), o epos não; por isso, ele deve ser banido. Portanto, há certa antitude não antirreligiosa, mas contra certa tradição já estabelecida.

Quanto à noção de physis, traduzido por natureza, Heidegger (1969), ele mesmo, esclarece as confusões reinantes. Physis é relacionada ao verbo phyein, que é "fazer crescer," originar; a tradução por "natureza" advém do fato dos filósofos romanos assim a terem tomado, enquanto "natura", talvez, em parte, porque a physis opõe-se ao nomos, ao "costume", por vezes também traduzida por "lei". Ademais, esta tradução deve ter sido reforçada pela significa de "ta physei onta ta physika", os entes naturais, restringindo, portanto, o significado das proposições dos pré-socráticoS a um setor do existente, tendo em conta a oposição frente ao nomos. A physis "é contraposta ao planejar e agir consciente dos homens, oposta ainda a tudo quanto seja feito, isto é, deve sua origem a outro ser, logo, à indústria, téchne, e à lei humana, nomos, à convenção thésis, e à inteligência abstrata nous (FRANK apud BERGE, p. 74). Em fato, no entanto, nos primeiros filósofos, como Anaximandro, encontra-se a noção de kosmos, de múltiplos significados, aparentado ao verbo kosmeo, "pôr em bela ordem", de modo que a reflexão não se limita as coisas naturais, abrangendo também as coisas do nomos e as

\footnotetext{
4 Tempo do passado no grego arcaico. O verbo grego além de voz e modo traz consigo a noção de aspecto, a qual indica se uma ação ocorreu uma ou repetidas vezes. Por meio do aoristo se indica que a ação ocorreu (ou ocorre) uma única vez.

${ }^{5}$ Citações e críticas a Homero: cf. DK 42, 55, 105; e a Hesíodo: cf. DK 40, 57, 196 in BERGE, 1969, pp. 231-298.
} 
da téchne (PRATES E SILVA, 1992). Em alguns fragmentos Heráclito se refere à physis em outros, ao kosmos (p.e., DK 30); em outros, a nenhum dos dois, somente a um "todos"6 (DK 53). Em ambos os casos, observe-se a não referência aos mitos, como Hesíodo, mas a tentativa de formulação de outra explicação, seja sobre do kosmos ou da physis.

Por fim, outro termo que cumpre precisar é aquele de pólemos, utilizado por Heráclito em dois fragmentos (DK 53 e 80). Alguns autores vão apontar uma distinção posterior ao período ora abordado, que tomará, de um lado, a guerra (pólemos) como guerra contra o estrangeiro (xénos), e a luta entre gregos será abordada enquanto stásis (dissenção, guerra civil); o termo stásis também era utilizado com um sentido de rebelião interna a um país, revolução, em outros autores bem como sua contraparte, a stásis (cf. SAINT-PIERRE, 1999, p. 35-37). Não temos razão para assim tão retamente interpretar o pensamento do Efésio, que viraria de pernas para o ar sua proposição (ver infra 6); contudo, note-se o seguinte: variadas palavras gregas exprimem a noção de luta, de embate; às duas acima poderíamos acrescentar, por exemplo, a noção de pálé ou agón ou maché, e muitas outras, com matizes diferentes, indicando a contenda entre partes diferentes. Em uma das traduções brasileiras, por exemplo, traduziu-se pólemos pó "combate", alterando-lhe consideravelmente o sentido, uma vez que o combate é indica uma noção pontual, um confronto único, conquanto guerra implica, antes, certo prolongamento de esforços. Em todo caso, a ontologia realista de Heráclito, cujo um dos pontos articuladores é a guerra, escolheu precisamente a noção de pólemos; primeiramente, se deve apontar que esta escolha coaduna com seu pensamento, visto que as coisas entre si discordam mas com um elemento unificador, o fogo, ou a guerra, ou seja, não é um disparate levado às últimas conseqüências (mesmo porque se tudo "segundo a discórdia (érin) vem a ser", desta discórdia vem "a mais bela harmonia”, DK 8); ademais, para que este raciocínio seja levado às últimas conseqüências, ele deve ser aplicado sobre si mesmo, ou seja, ele mesmo deve estar em guerra - e de fato estavam, como estamos tentando provar.

\footnotetext{
${ }^{6}$ Pólemos oánton mèn patér esti, pánton, dè basileús, kaì toús mèn theoùs édeixe toús dè antrópous, tous mèn doúlos epoíese toùs dè eleutérous" (DK 53 in BERGE, 1969, p. 260); "a guerra é de todas as coisas pai, uns reis outros deuses estabeleceu, de uns escravos fez de outros livres" (a tradução é nossa). O termo utilizados é, portanto, pánton, “de todos" ou "de todas".
} 
Tem-se, pois, que a partir de certas escolhas de vocabulário, os préssocráticos, sobretudo Anaximandro e Heráclito, davam indicativos da constituição de certo discurso contrário aos mitos formadores da Grécia no período homérico. E quanto ao segundo ponto que indicamos como característico de sua formação

De modo geral, a filosofia teria nascidos em meados do século VI a.C. nas colônias gregas da Ásia Menor e da Magna Grécia, em decorrência seja de seu caráter talossocrático, seja de uma menor pressão das hierarquias e mentalidade religiosa e, também, pela constante pressão reliazadas por outros povos nas fronteiras. De todo modo, aponta-se variados denominadores comuns para os pressocráticos, como entendimento da existência de uma arché da physis (o que não é de todo exato), à qual cumpre analisar; forte presença de elementos tidos como naturais, tais como água e fogo, muitas vezes tomados como essenciais em relação ao conjunto da physis; e tentativa de subsunção da totalidade à estes elementos. Embora Aristóteles os caracterize como físiólogos, em fato, em muitos destes filósofos encontramos reflexões éticas ou políticas, de modo a não ser justa esta apreciação do Estagirita, mesmo porque, como se viu, por vezes não há referência à physis, por vezes a referência é a um kosmos, que pode ser tomado como correlato do ser. À luz de nossos apontamentos etimológicos bem como da acontecimentalização dos primeiros filósofos (LUIZ, 2013a), cumpre reavaliar, em fato, os pressocráticos tendo em conta nossos fins.

\section{Conclusões}

Para nós, pois, a filosofia pode ser marcada como estratégica desde o ponto de vista dos termos-chave que articular, como por ter ocorrido em um mundo regrado pela religião ou pelos mitos e a ele ter se oposto. A conjugação desta terminologia não deixa dúvidas que se trata de descobrir ou formular o que comanda (archein) a ordem cósmica inclusive a das coisas humanas (kosmos) ou a da natureza (physis). Para alguns em um marco explícito de que tudo resolve-se na guerra (pólemos), inclusive contra os mitos épicos (epos) contra os quais é mister estar atento ao que presentemente advêm (logos). Destarte, contra uma determinada visão de mundo que a filosofia guerreia, buscando novas explicações, contrárias àquelas. Neste sentido, tomamos que a filosofia é uma estratégia sem sujeito, vincada pela belicosidade na medida em que acontece. 
Para Heidegger ${ }^{7}$, como se viu, a história da filosofia seria marcada por uma queda, na medida em que, em seus primórdios, encaminhava-se para uma reflexão ontológica, posteriormente suplantada pelo domínio progressivo da técnica. Contudo, em termos aristotélicos, este primeiro tempo da filosofia seria marcado pela tentativa de conhecimento das causas primeiras, do princípio que governa o que faz vicejar o todo. A filosofia, enquanto saber historial não nos parece ser, deste modo, oposta à técnica, posto que, desde suas primeiras afirmações, com Anaximandro e o apeíron tem-se a intenção de formular um discurso que seja a arché do kosmos, quer dizer, um gênero de saber que comande a ordem cósmica; em outra ocasião, chamamos isto de técnica de totalidade (LUIZ, 2013a). Evidentemente, diferenças devem ser marcadas com relação a técnica propriamente falando, como aquela do artesão que Aristóteles aborda e Heidegger analisa (HEIDEGGER, 1958, pp. 9-48), mesmo porque, na análise heideggeriana entram em cena as quatro causas aristotélicas. Para Heidegger, " a técnica é, em sua essência, um destino ontológico-historial da verdade do ser, que reside no esquecimento" (HEIDEGGER, 1987, p. 67). A nosso ver, a questão se assoma de outro modo. Contudo, se de saída este objetivo de conhecimento da causa primeira se marca, isto não implica que a filosofia esteja marcada por ele como um telos inexorável, através do qual os acontecimentos decorreriam necessariamente, tal qual quer Hegel, posto que, neste caso, não entram em cena aspectos decisivos a nosso ver, tais sendo os combates que determinaram o desenrolar dos fatos, como as disputas entre as diferentes correntes para determinar o que viria a ser a própria filosofia; ademais, o surgimento de variadas ciências, que se apossaram de plagas do outrora campo filosófico, terminaria por minguar a filosofia, terminando por não dar conta de explicar, em um marco teleológico, seu desenrolar.

Se a filosofia é historial, quer dizer, se ela traz consigo um destino construído na história, este não deve ser entendido não como telos, tampouco enquanto luta entre distintas correntes, como quer seja Nietzsche seja Foucault. É enquanto estratégia, ou,

\footnotetext{
7 É conhecida a afirmação de Aristóteles segundo a qual a filosofia teria nascido do ócio (ARISTÓTELES, 981b) e do maravilhamento (thaumazeim) (idem, 982b) frente à existência do existente. Heidegger opõe este surgimento da filosofia ao da técnica, enquanto para nós deve-se entender uma como decorrente da outra (a filosofia do conhecimento técnico; cf. LUIZ,, 2013a). Em certa passagem do Órganon, Aristóteles regojiza-se com o fato de estar elaborando o primeiro compêndio concernente às regras do pensar válido: "No nosso estudo, porém, não aconteceu que parte do trabalho tivesse sido realizada antes, deixando outra parte por completar. Não existia absolutamente nada". (ARISTÓTELES, 1987, 183a-192b). Esta formulação do pensar é entendida por Heidegger como estando na raiz do esquecimento do ser, posto que é técnico-teorética.
} 
antes, enquanto metaestratégia, ou seja, estratégia que comporta distintas outras. Com isto queremos dizer então, que a filosofia se opôs a um tipo de explicação míticoreligiosa e que, mesmo quando operou pari passu com a religião, trazia consigo elementos que operavam contra esta mesma religião; e que ela formulou, em seus princípios, certos objetivos que busca concretizar por meio de determinadas táticas.Ora, o conhecimento das causas primeiras ou a formulação de uma ontologia, que em exaurindo o ser, exaura cada ente particular, não é este o objetivo primeiro, na ordem do tempo e da meta, da filosofia? A técnica ou, mais amplamente, a ciência não seriam, pois, opostos à filosofia, mas suas aliadas, ou, antes, suas táticas, havendo outras, na medida em que aconteceram em derivação deste tipo de conhecimento que a filosofia propugna? Em fato, os recentes avanços seja nas ciências da informação seja na neurociência ou na robótica - como implantes neurais ou a criação da nuvem indicam mais claramente a aproximação dos objetivos da filosofia, algo que nós chamamos de maquinidade em oposição à humanidade; esta, seja a dos socialistas, seja a dos liberais ou, até mesmo, em suas formas cristãs, nunca chegou a se constituir, pelo simples fato da comunidade humana não ter se formulado enquanto tal, visto parte considerável do gênero humano ser objetificada sob variadas formas. Implantes, exoesqueletos, dentre outros, apontam, estes sim, para a superação de limites do ente que dorme, sonha, defeca, etc., em benefício de entes não mais circunscritos a mera animalidade e capazes, estes sim, de, tendo por base sua imortalidade e, mesmo, sua condição quase inefável, de apreender indefinidamente conhecimentos e, assim, quem sabe, travar contato com o absoluto sem correr os riscos da loucura ou da morte, tudo à base do advento da máquina. E mesmo a divisão da filosofia em diferentes disciplinas não indicaria, de preferência, a adoção de uma estratégia de dividir para conquistar, possibilitando, assim, que se alcance o fim almejado desde o princípio?

\section{Bibliografia}

ANAXIMANDRO DE MILETO; Doxografia, fragmentos, crítica moderna in SOUZA, J. C. de et alii.; Os pré-socráticos, SP: Abril, 1978, $2^{\text {a }}$ ed. 
BARNES, J; Filósofos pré-socráticos, SP: Martins Fontes, 2003

BEAUFRET, J.; Introduction a une lecture du poème de Parménide in Le poème de Parménide, Paris: PUF, 1955

BERGE, D.; O logos heraclítico: introdução à leitura dos fragmentos, RJ: Instituto Nacional do Livro/MEC, 1969

CASTRO, E.; Vocabulário de Foucault, BH: Autêntica, 2009

CRESSON, A.; A filosofia antiga, SP: Difusão Européia do Livro, 1960, $2^{\text {a }}$ ed.

FOUCAULT, M.; Em defesa da sociedade, SP: Martins Fontes, 2005

; Microfísica do poder, RJ: Graal, 2007

; Nietzsche Freud Marx; Theatrum Philosophicum, SP: Princípio, s/d, disponível em http://pt.scribd.com/doc/22082432/Foucault-Michel-NietzscheFreud-e-Marx

GLULIEMINI, J.P.; Le grec ancien, Poitiers: Assimil, 2003

HEIDEGGER, M.; Carta sobre o humanismo, Lisboa: Gumarães Editores, 1987, $3^{\text {a }}$ ed.

; Essais et conférences, Paris: Gallimard, 1958

; Introdução à Metafísica, s/l: Tempo Brasileiro, 1969, $2^{\mathrm{a}}$ ed.

; Qu'est-ce que ce — la philosophie, Paris: Gallimard, 1957

HEGEL, G.W.F.; Introdução à história da filosofia, SP: Hemus, 1983

; Preleções sobre a história da filosofia in SOUZA, J. C. de et alii.;

Os pré-socráticos, SP: Abril, 1978, $2^{\mathrm{a}}$ ed.

HERÁCLITO DE ÉFESO; Doxografia, fragmentos, crítica moderna in SOUZA, J. C. de et alii.; Os pré-socráticos, SP: Abril, 1978, 2a ed. 
; Fragmentos in BERGE, D.; O logos heraclítico: introdução

à leitura dos fragmentos, RJ: Instituto Nacional do Livro/MEC, 1969

; Fragmentos contextualizados, Lisboa: Imprensa Nacional-

Casa da Moeda, 2005

LIBERA, A. de; A filosofia medieval, RJ: Jorge Zahar, 1990

LUIZ, F.; A filosofia, a dominação, Revista Espaço Livre, vol. 8, num. 16, jul. dez. $2013 \mathrm{a}$

; A relação entre verdade e política em Foucault, Marília: Filogênese, no 1, vol. 1, 2008

Foucault genealogista: a guerra como modelo analítico das relações de poder, Campinas: Cadernos da Graduação, v. 1, p. 145-152, 2010

; O conceito de saber na epistemologia política de Michel Foucault, Marília: Revista de Iniciação Científica da FFC, Vol. 10, No 2, 2010b, disponível em http://www2.marilia.unesp.br/revistas/index.php/ric/article/viewFile/331/379

; Precisões sobre o conceito de filosofia da guerra, Marília: Filogênese, vol.

7, no. 2, 2014b disponível em http://www.marilia.unesp.br/Home/RevistasEletronicas/FILOGENESE/2_felipeluiz.pdf ; Sentido da vida como determinação política, Marília: 2013b, mim.

NIETZSCHE, F.; A filosofia na época trágica dos gregos in SOUZA, J. C. de et alii.; Os présocráticos, SP: Abril, 1978, $2^{\text {a }}$ ed.

SP: Cia. das Letras. 1999

O nascimento da tragédia ou helenismo e pessimismo, PESSANHA, J.A.M,; Do mito à filosofia in SOUZA, J. C. de et alii.; Os pré-socráticos, SP: Abril, $1978,2^{\text {a }}$ ed.

PARMÊNIDES DE ELÉIA; Le poème de Parménide, Paris, PUF, 1955

PRATES E SILVA, R.C.B.; A justiça cósmica (um estudo bre Anaximandro de Mileto), Tese de Livre-docência, Araraquara: FCL-UNESP, 1992

SAINT-PIERRE, H.; Política armada --- fundamentos da guerra revolucionária, SP: EDUNESP, 1999 
SCHOPENHAUER, A.; Metafísica do belo, SP: EDUNESP, 2003

SOUZA, J. C. de et alii.; Os pré-socráticos, SP: Abril, 1978, $2^{\mathrm{a}}$ ed.

Recebido em agosto de 2016

Aceito em junho de 2017 